\title{
Atmospheric input of lead into the German Bight- a high resolution measurement and model case study
}

\author{
K. Heinke Schlünzen ${ }^{1, *}$, Thomas Stahlschmidt ${ }^{2}$, Andreas Rebers ${ }^{2}$, Ulrike Niemeier ${ }^{1}$, \\ Michael Kriews ${ }^{3}$, Walter Dannecker ${ }^{2}$
}

\author{
${ }^{1}$ Zentrum für Meeres- und Klimaforschung der Universität Hamburg, Meteorologisches Institut, Bundesstr. 55 , \\ D-20146 Hamburg, Germany \\ ${ }^{2}$ Institut für Anorganische und Angewandte Chemie, Universität Hamburg, Martin-Luther-King-Platz 6, \\ D-20146 Hamburg, Germany \\ ${ }^{3}$ Alfred-Wegener-Institut für Polar- und Meeresiorschung, Postfach 120161, D-27515 Bremerhaven, Germany
}

\begin{abstract}
The atmospheric input of lead into the German Bight is calculated from measured atmospheric concentrations, from modelled as well as measurement-derived deposition velocities, and from measured wet deposition values, with a temporal resolution between 6 and $24 \mathrm{~h}$. The measurements were taken at several coastal sites and on a ship in the German Bight during a 1 wk drift experiment in April 1991. The applied model is a 3-dimensional nonhydrostatic atmospheric mesoscale model. The calculated input data depend on deposition velocities and integration time. Due to variation in dry deposition the atmospheric input values can differ by a factor of 3 . Total deposition values and thus atmospheric input data can differ by a factor of 10. Calculated backward trajectories show that the observed time-lag in the occurrence of concentration maxima can be explained by the travel time of the advected air masses between the measurement sites. By use of backward trajectories and results of the mesoscale model the measured values are associated with source areas for a day with very high atmospheric lead concentrations. It is shown that up to $50 \%$ of the contaminants can reach the German Bight via long-range transport. Mesoscale atmospheric phenomena also influence the wind field and the concentrations.
\end{abstract}

KEY WORDS: North Sea $\cdot$ German Bight $\cdot$ Atmospheric input $\cdot$ Dry deposition $\cdot$ Wet deposition $\cdot$ Atmospheric lead concentration. Mesoscale model

\section{INTRODUCTION}

The pollution of marginal seas is caused by inputs not only from rivers, coastal industries, and dumping but also from the atmosphere in considerable amounts. This is especially true for the North Sea, which is situated close to major industrial centres and highly populated areas. The input quantities have been widely discussed in earlier papers (e.g. INC 1987, Warmenhoven et al. 1989, QSR 1993) and thus are only briefly summarized here. Fig. 1a shows the relative contributions of the atmosphere and other paths for the whole North Sea area. The values are based on the data compiled

•E-mail: schluenzen@dkrz.de for the Second International North Sea Conference (INC 1987). The input via the atmosphere amounts to more than two thirds of the total for cadmium and lead and to more than one third for zinc and copper. The data for the German Bight compiled in Fig. 1b are based on the input values for the Wadden Sea area (Schlünzen 1994a) recalculated for the German Bight (area: $24000 \mathrm{~km}^{2}$ ). Due to the proximity of the river estuaries, the proportion of the atmospheric input is lower for the more coastal area compared to the whole North Sea. However, it still accounts for a considerable amount of lead and cadmium as well as of some organic contaminants which are not regarded here.

The relative contributions given in Fig. 1 correspond to annual means. These are strongly influenced by 


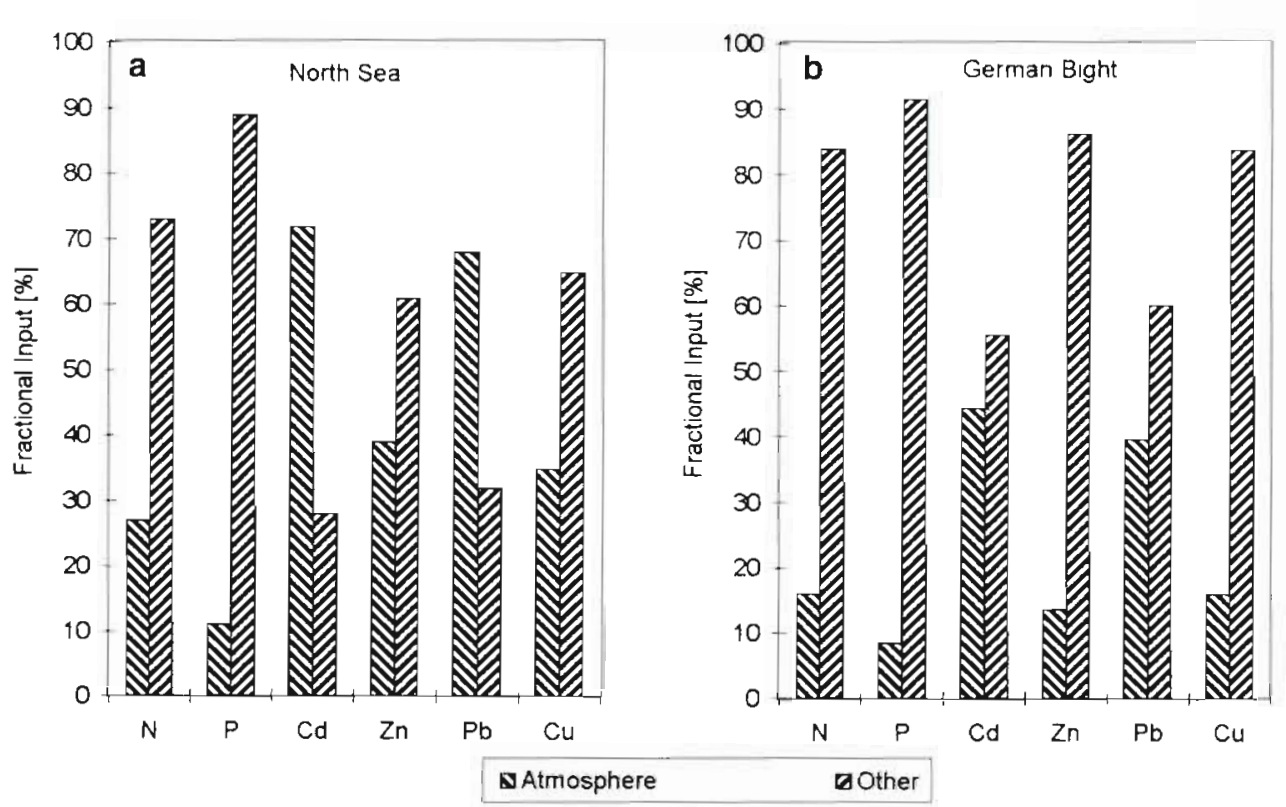

Fig. 1. Fractional inputs $(\%)$ into (a) the North Sea (data from INC 1987) and (b) the German Bight (data from Schlünzen 1994a) short-term deposition events, as has been derived from long-term investigations (Dannecker et al. 1994, Kersten et al. 1994). Measurements and model results show that the atmospheric input can change considerably within $1 \mathrm{~d}$. This can be caused by changes in contaminant concentration in air due to a wind shift, as shown in this paper (factor of 50: section 'Measured concentrations' below), and by changes in deposition velocity due to different atmospheric stratification and wind velocity (factor of 2: Schlünzen \& Krell 1994). Additionally, wet deposition can enhance dry deposition by up to a factor of 10 within a few hours (section 'Calculated atmospheric input...' below; Spokes et al. 1993). For this reason, studies of transfer processes in the ecosystem as described by Sündermann (1997 in this volume) need input data with a temporal resolution of a few hours.

To investigate the transfer processes in the German Bight ecosystem, lead was used as a key contaminant in the German research project PRISMA. Lead is released into the marine environment by river discharges, atmospheric deposition, remobilization from sediment and removal from bacterio-, phyto-, zooplankton and other biota it might be incorporated within or attached to. The accumulation factors for phytoplankton can be much higher for lead than they are for other heavy metals (Karbe et al. 1994). Most lead, however, is bound to the body surface and only a little is incorporated. Therefore, lead is a less crucial heavy metal for the plankton than e.g. mercury is. Nevertheless, lead is suitable for studying temporal concentration changes in the ecosystem, because it is found and can reliably be measured in all compartments of the ecosystem (including the atmosphere:
Kersten et al. 1992, Kriews 1992, Krause et al. 1994). In addition, the atmospheric transport and deposition of other heavy metals like cadmium is similar to that for lead, which makes lead a very good example for studying the atmospheric input.

Since the atmospheric contribution to the mean input is high for lead (see Fig. 1) some effort has to be made to estimate the atmospheric input of lead into the sea at a resolution matching the measurements in the water. Since it is not possible to measure the dry deposition directly with a high temporal resolution, the values presented in this paper are calculated from high resolution concentration measurements (section 'Measuring atmospheric concentrations') and model results (section 'Modelling atmospheric concentrations and deposition'). The resulting deposition values and derived input data are given in the section 'Calculated atmospheric input...'.

\section{MEASURING ATMOSPHERIC CONCENTRATIONS}

The atmospheric concentrations of lead and other heavy metals were measured at 5 sites in the area of the German Bight during the first PRISMA experiment. It was performed in April 1991 and included 3 driftexperiment periods. Details on the experiment are given by Brockmann et al. (1997 in this volume). Below, atmospheric concentrations and the atmospheric input are presented for the third drift period (April 23 to 30, 1991). Measurements and model results for other compartments of the ecosystem are given by König et al. (1997), Moll (1997) and Raabe et al. (1997) (all in this volume). 


\section{Measurement strategy}

During the experiment, bulk aerosol samples were taken on board the RV 'Valdivia', from which measurements in the water column were also performed. For interpretation of the measured atmospheric concentrations, additional samples were taken at the German research platform Nordsee (FP 'Nordsee'), at the isle of Helgoland, and at 2 coastal measurement sites, namely Westerhever on the Eiderstedt peninsula and Neuharlingersiel on the East Frisian coast (see Fig 8 for the location of the sites). The sampling intervals were scheduled on board RV 'Valdivia' depending on the local wind direction and in consistency with other meteorological measurements, e.g. the rawinsonde ascents (Schrum et al. 1997 in this volume). During periods of easterly wind directions, when air masses of continental origin were advected, the temporal resolution of the measurements was increased. The atmospheric aerosol was accumulated for $6 \mathrm{~h}$, thus the measurements were 6-hourly integrations. For westerly wind directions, when the advected air was very clean, the intervals were extended to $24 \mathrm{~h}$. The measured air concentrations confirmed this sampling strategy, since they clearly changed for different wind directions during the drift experiment.

Aerosol was collected at a fixed inlet velocity on prewashed cellulose nitrate filters under non-isokinetic conditions. Under these conditions, the upper size limit of the collected particles depends on the wind velocity (Zebel 1979). The maximum aerodynamic diameters lie at about $30 \mu \mathrm{m}$ for no-wind conditions (Kriews 1992) and are lower for higher wind velocities. Trace element analysis was performed with Graphite Furnace Atomic Absorption Spectrometry (GF-AAS) after a wet oxidative acid digestion procedure. Rain samples were collected with a specially prepared funnel on an event basis on board RV 'Valdivia' and with automatic rain collectors or bulk samplers at Westerhever and Neuharlingersiel. On board RV 'Valdivia' sample preparation and handling were carried out under clean room conditions. Sampling and analytical techniques are described in detail by Kriews (1992) and Schulz (1993).

\section{Measured concentrations}

At the beginning of the drift experiment (April 23) the observed atmospheric lead concentrations were low (Fig. 2), because comparatively unpolluted air masses were advected from the northwest. Intense precipitation events preceding the measuring campaign additionally reduced the concentrations in air. During April 24 the lead concentrations distinctly increased (factor of 50) with values above $30 \mathrm{ng} \mathrm{m}^{-3}$ at RV 'Valdivia'. Backward trajectories were calculated to explain concentration trends during the drift experiment and to associate the measured concentrations with the origin of the air masses.

Fig. 3 shows backward trajectories for April 24 calculated for the measurement sites RV 'Valdivia' (Fig. 3a) and Westerhever (Fig. 3b). From 00:00 to 06:00 h UTC air masses from the northern North Sea reached RV 'Valdivia' carrying low contaminant concentrations. During the day, the wind turned from northerly via northeasterly to easterly directions, and the air masses passed Denmark; in the afternoon they were of continental origin. The concentrations measured at Westerhever were high most of the day. The corresponding trajectories (Fig. 3a) show the influence of continental air masses for April 24 and northerly wind directions for the day before (not shown here). With an average wind velocity of $3 \mathrm{~m} \mathrm{~s}^{-1}$ air masses that passed Westerhever during the night hours could have arrived at RV 'Valdivia' on the morning of April 24, about 10 h later. Thus the high concentrations observed at Westerhever and the more westerly sites FP 'Nordsee' and RV 'Valdivia' might originate at the same sources, with the time-lag in occurrence to be explained by the travel time of the air. The sources were possibly in Jutland or
Fig. 2. Atmospheric lead concentrations $\left(\mathrm{C}_{\mathrm{Pb}}\right)$ measured at (a) RV 'Valdivia' and Westerhever, and (b) other sampling sites between April 23 and 30,1991
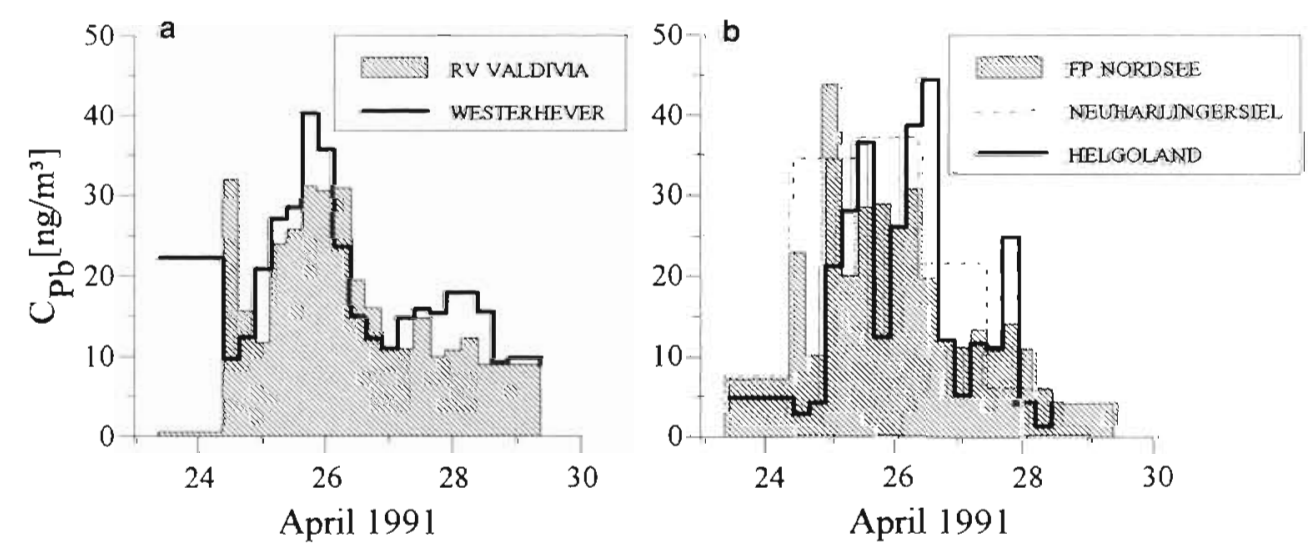

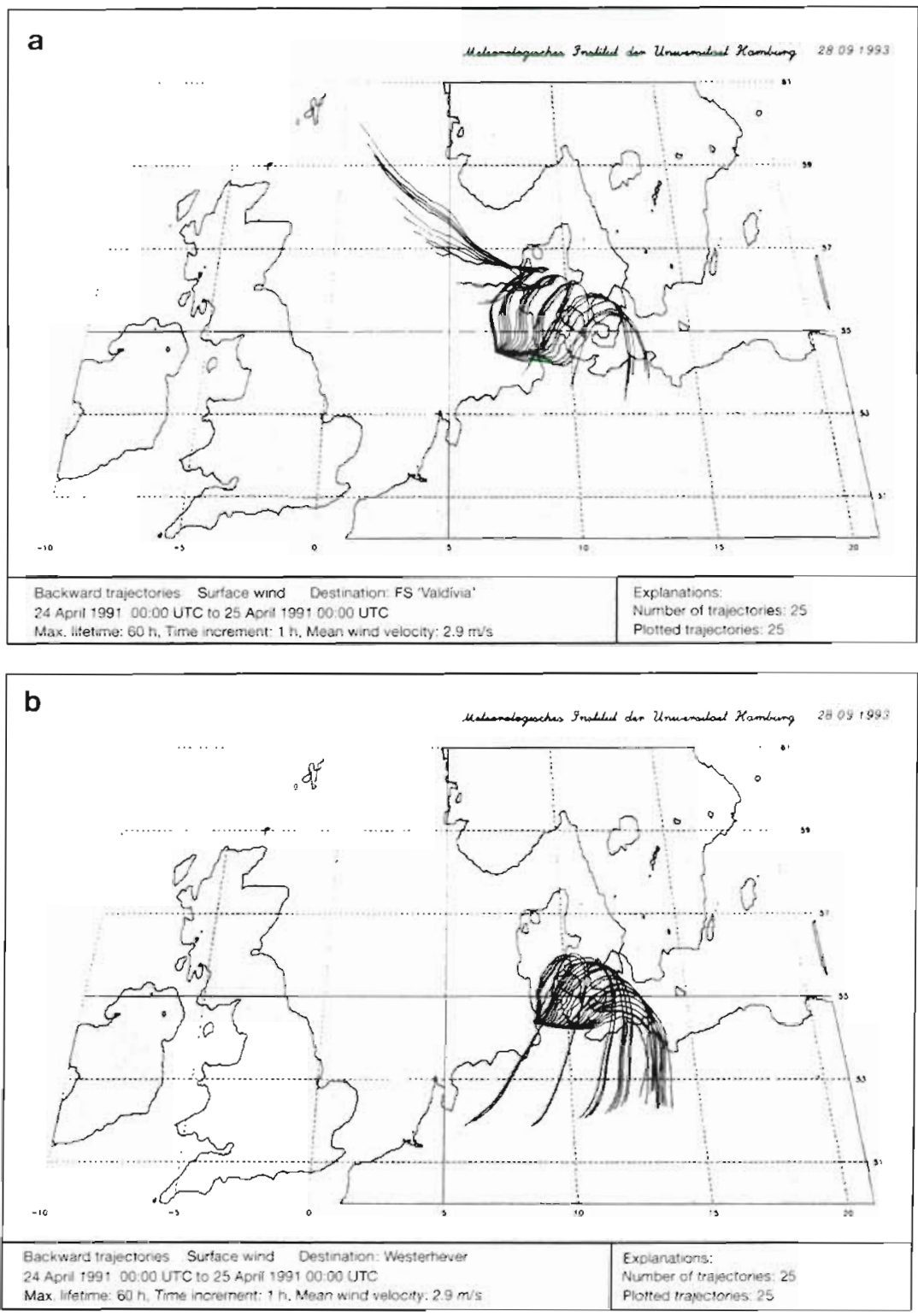

Fig. 3. Backward wind trajectories for (a) RV 'Valdivia' and (b) Westerhever for April 24,00:00 to 24:00 h UTC
Fig. 4 shows backward trajectories for April 25 to 27, 1991, calculated for RV 'Valdivia', During this time interval, air masses with high concentration levels reached RV 'Valdivia' as well as the other measurement sites. As can be seen from the backward trajectories, the sampled air masses had somewhat different origins during the 2 days. On April 25 the air crossed SchleswigHolstein and was possibly of continental origin again. Thus, highly polluted air was advected. During April 26 the wind changed slightly to northeasterly directions, and air masses transported over the Baltic Sea, passing the southern region of Sweden, reached the sampling site. The concentrations decreased during April 26. Rain events which were observed over land can only partly explain the reduction; it was mainly caused by the wind shift and thus differences in the source areas.

In the following days the measured atmospheric concentrations were around $10 \mathrm{ng} \mathrm{m}^{-3}$ at RV 'Valdivia', and the probed air masses at the measurement sites were mainly advected from northerly and northeasterly directions. The concentrations were at times reduced by precipitation which occurred over land, over the German Bight, and around the ship. On the 28th RV 'Valdivia' was in a precipitation area and wet deposition samples could be taken at this site. over the continent, but not close to the German Bight. On the same day, the concentrations were still low at the more southerly measurement site Helgoland, whereas the East Frisian coastal measurement site Neuharlingersiel showed higher concentrations (Fig. $2 b)$. The difference can be explained by the mesoscale flow pattern (see Fig. 6) which shows that different air masses are advected to these measurement sites. Possibly, these 2 air masses have different sources situated close to the German Bight. These hypotheses are confirmed by the mesoscale model results, as will be shown below ('Modelling atmospheric concentrations and deposition-Model results')

\section{MODELLING ATMOSPHERIC CONCENTRATIONS AND DEPOSITION}

The model calculations were performed using the 3dimensional, nonhydrostatic atmospheric mesoscale transport and flow model METRAS. The model was developed at the Meteorological Institute, University of Hamburg, for the calculation of atmospheric flows in the mesoscale- $\gamma$ and mesoscale- $\beta$ range (Schlünzen 1990, Wu \& Schlünzen 1992, Niemeier \& Schlünzen 1993) and for pollution transport studies especially in coastal areas (Schlünzen \& Pahl 1992, Schlünzen 1994a, Schlünzen \& Krell 1994). In the present paper 
the model is used to calculate the deposition velocity and is applied in a 3-dimensional case study of lead deposition.

\section{Description of the atmospheric transport model}

An explicit description of the model is given in Schlünzen (1988, 1990) and Schlünzen et al. (1996). The main features are typical for nonhydrostatic mesoscale models, as can be seen from Schlünzen (1994b). Here, only those qualities of the model are described in detail which are important for the simulation of contaminant transport over coastal areas and for modelling dry deposition.

The model is based on the fundamental conservation principles of fluid dynamics, namely those of mass, momentum and energy. Wind field, temperature, humidity, cloud and rainwater content, as well as tracer concentrations are calculated from prognostic equations, pressure and density from diagnostic ones. The subgrid-scale turbulent fluxes important for the dispersion of emitted contaminants are parameterized with a first-order closure scheme. The determination of exchange coefficients dependent on wind shear and atmospheric stratification follows Dunst (1982). A surface energy budget equation is applied to compute the time-dependent surface temperature over land and mudflats. A corresponding equation is used for humidity. Dry deposition is calculated as a function of deposition velocity $V_{\mathrm{d}}$ and concentration $C$ at the lowest grid point above the surface, following the resistance model concept (e.g. Chang et al. 1987):

$$
V_{\mathrm{d}} \cdot C=\left(r_{\mathrm{a}}+r_{\mathrm{m}}+r_{\mathrm{s}}\right)^{-1} \cdot C
$$

The atmospheric resistance $r_{\mathrm{a}}$ depends on the calculated wind velocity and atmospheric stability. For gases, the sublayer resistance $r_{\mathrm{m}}$ and the surface resistance $r_{\mathrm{s}}$ both have to be taken into account. The sublayer resistances are calculated with respect to different land use characteristics (urban areas: Brutsaert 1975; vegetation, mudflats: Weseley \& Hicks 1977;
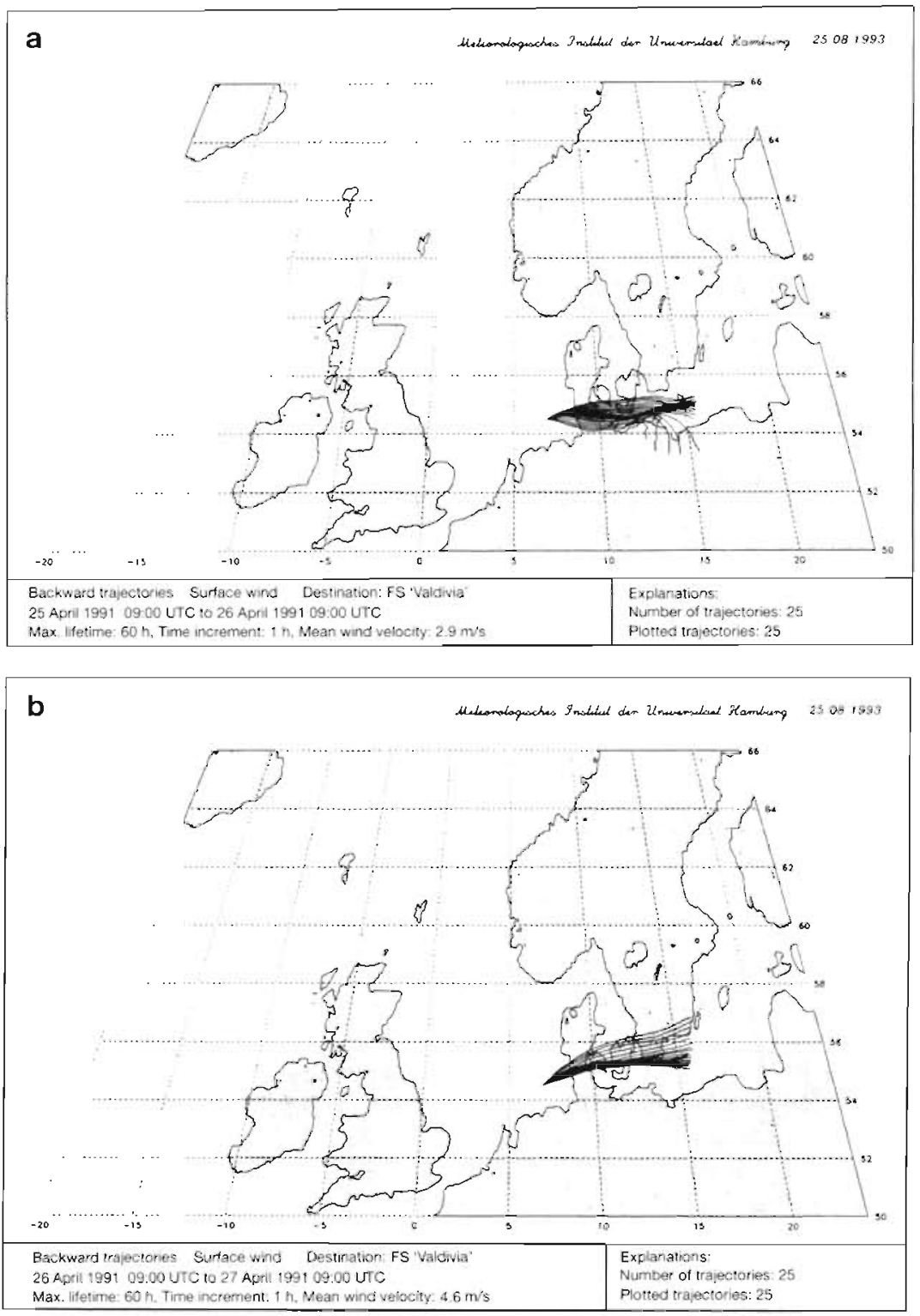

Fig. 4. Backward wind trajectories for RV 'Valdivia' for (a) April 25, 09:00 h UTC. to April 26, 09:00 h UTC, and (b) Apri 26, 09:00 h UTC, to April 27, 09:00 h UTC

water: Garratt \& Hicks 1973). These are also considered in the values for the surface resistances, which are taken from Walcek et al. (1986). The deposition velocity of lead is determined differently, since lead is transported on aerosols of a particle size between 0.1 and $1 \mu \mathrm{m}$ (Seinfeld 1986). Following Voldner et al. (1986), the surface resistances $r_{s}$ are taken to be zero for particles. The values for the sublayer resistances $r_{\mathrm{m}}$ depend on land use characteristics and short wave radiation. Over water, the sublayer resistance is zero, resulting in higher deposition velocities over water compared to the values over land. Neglecting the sublayer resistance $r_{\mathrm{m}}$ over water is equivalent to neglecting 
smaller particles in this area. In the present study only hygroscopic aerosols (e.g. sulphate) of a particle size above $0.8 \mu \mathrm{m}$ are considered in the modelled deposition velocities. Thus, the deposition velocities calculated here are in the high end of the possible range.

With the described features, the atmospheric mesoscale model can be applied to simulate a realistic diurnal cycle of the atmospheric boundary layer height and of vertical mixing, as well as of wind, temperature, humidity, and precipitation fields. In addition, the tracer transport and dry and wet deposition can be calculated at a high temporal and spatial resolution. Thus the deposition velocity and the atmospheric concentration can be calculated at the same temporal resolution as is necessary for comparison with and interpretation of measurements.

\section{Model results}

In the case study presented in this paper, cloud development and wet deposition processes have not been included, because wet deposition took place directly at the measurement site RV 'Valdivia' only for a few hours (see the section 'Measured concentrations' above).

The 1-dimensional version of the mesoscale model METRAS was applied to calculate the dry deposition velocity corresponding to the measurement intervais given in Fig. 2. The model was initialized for a neutral atmospheric stratification and with the wind velocities measured at RV 'Valdivia' (Schrum et al. 1997). The resulting deposition velocities are given in Fig. 5. Most of the time the simulated deposition velocities are around $0.6 \mathrm{~cm} \mathrm{~s}^{-1}$. On April 27 the values are highest $\left(1.7 \mathrm{~cm} \mathrm{~s}^{-1}\right)$, because the wind velocities were above $10 \mathrm{~m} \mathrm{~s}^{-1}$ for some hours. The modelled values are in the range given by measurements over the Great Lakes

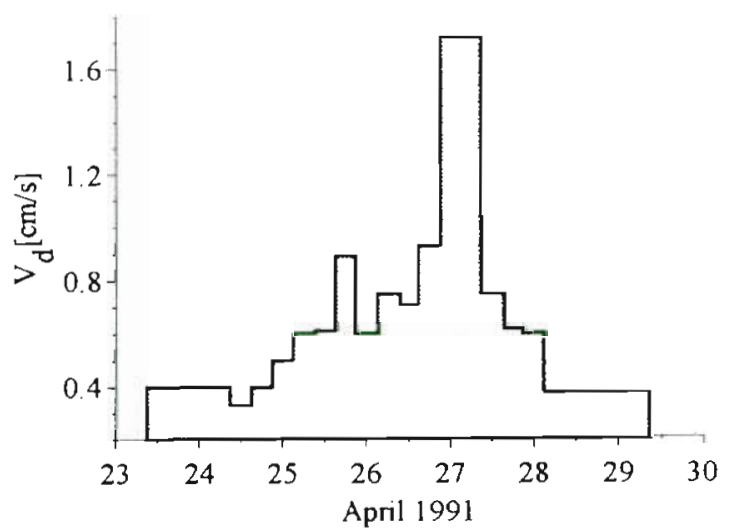

Fig. 5. Simulated deposition velocities for lead, dependent on measured wind velocitles at RV 'Valdivia' for the measurement intervals given in Fig. 2a
(Voldner et al. 1986) and above the values (by a factor of 2 to 10) calculated from impactor measurements (Steiger et al. 1989, Kriews 1992, Dannecker et al 1994). The discrepancy can be explained by the aerosol spectrum, for which different assumptions are made when calculating deposition velocities in the model and from the impactor measurements. In the aerosol spectrum applied to measurements, the particle growth due to the high humidity over water surfaces and thus the increase in aerosol mass is not considered. In contrast, the METRAS model results are based on the assumption that lead is transported over water on sulphate aerosol which has grown (particle size above $0.8 \mu \mathrm{m}$ ). Both calculations neglect the bimodal particle size distribution found over the sea (Steiger et al. 1989, Schulz et al. 1994). For this reason, the modelled deposition velocities characterise the upper limit of the deposition velocity values, whereas the deposition velocities calculated from the impactor measurements mark the lower limit for $V_{d}$ over water.

Very high concentrations were measured at the northern sampling sites on April 24. For this day backward trajectories show that long-range transport might have caused the high concentrations (section 'Measured concentrations' above). To confirm this hypothesis, the 3-dimensional version of the METRAS model was applied. The model was initialized with mean profiles derived from the rawinsonde data taken from RV 'Gauss' (April 23: 10:00 h UTC; April 24: 10:00, 16:00, 22:00 h UTC), which was close to RV 'Valdivia' in the German Bight. The mean stratification in the atmosphere generally was slightly stable with an inversion at an altitude of $2000 \mathrm{~m}$. The wind velocity close to the ocean surface was $4.2 \mathrm{~m} \mathrm{~s}^{-1}$ from the northeast and the water temperature was $7.2^{\circ} \mathrm{C}$. For details on the meteorological situation see Schrum et al. (1997). The lead emission data for Germany were taken from Münch \& Axenfeld (1990); they correspond to emission values for 1987 . Because of the emission reductions carried out in Germany in the meantime, the values used in the model for Germany lie above the emissions for 1991 The sources in the model areas representing Denmark and the Netherlands were appropriately estimated, but point sources were neglected.

In Fig. 6 the simulated wind and temperature fields are given for a height of $10 \mathrm{~m}$ above the ground for 08:00 and 14:00 h UTC. In the morning the fields are quite homogeneous - the air temperature over the land is about $2^{\circ} \mathrm{C}$ higher than over the German Bight. The wind comes from easterly directions and the wind velocity is slightly higher over the German Bight ( 3 to $4 \mathrm{~m} \mathrm{~s}^{-1}$ ) than over land ( 1 to $2.5 \mathrm{~m} \mathrm{~s}^{-1}$ ). During the day, the temperature rises up to about $12^{\circ} \mathrm{C}$ over the land surfaces (Fig 6b). Since the temperature over water does not change correspondingly, the resulting tem- 

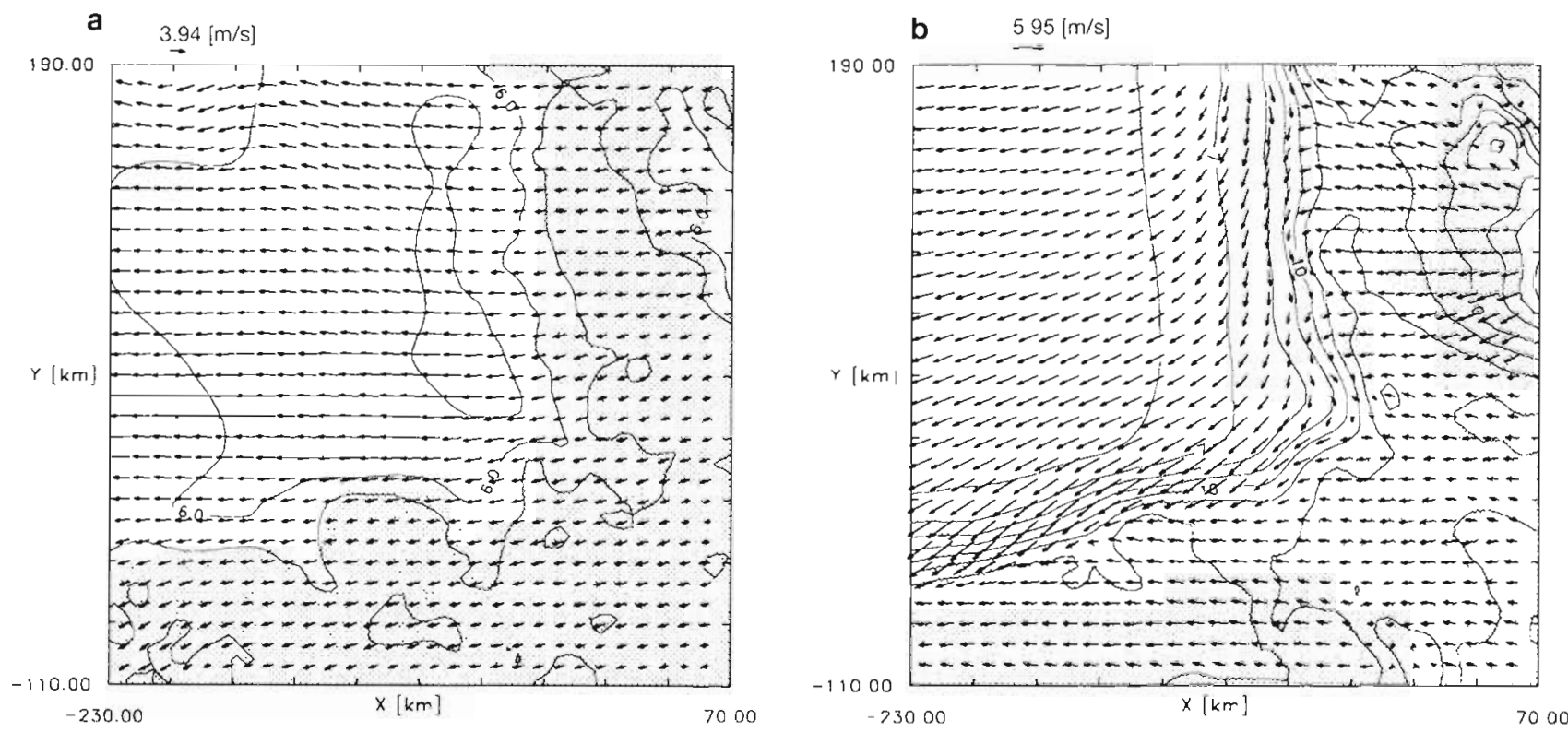

Fig. 6. Simulated wind and temperature field for the area of the German Bight for Aprl 24 (a) $0800 \mathrm{~h}$ UTC, (b) 14:00 h UTC Temperature increment is $1^{\circ} \mathrm{C}$

perature difference at the coast causes a convergence zone with a wind parallel to the coast. At the East Frisian coast the modelled wind velocity is highest (up to $6 \mathrm{~m} \mathrm{~s}^{-1}$ ) whereas it is lower in the area of the German Bight ( 3 to $6 \mathrm{~m} \mathrm{~s}^{-1}$ ), at the North Frisian coast and over land (both 1 to $3 \mathrm{~m} \mathrm{~s}^{-1}$ ). The simulated wind and temperature fields correspond to the observed wind directions and temperatures over land, but show a difference in wind direction of $30^{\circ}$ relative to the directions measured at RV 'Valdivia'

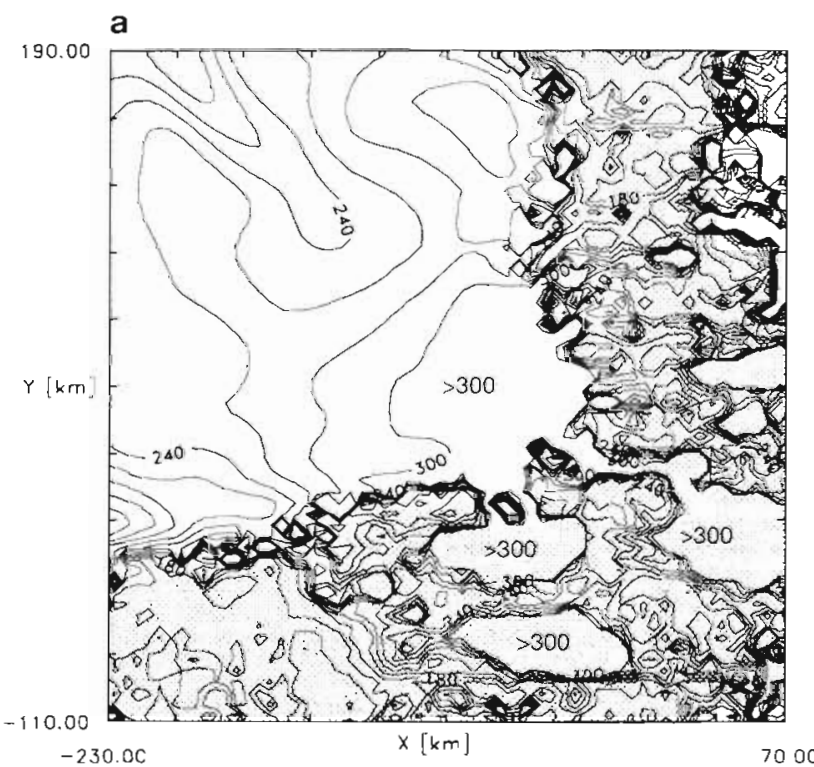

The wind fields influence the deposition field as can be seen from Fig. 7 The hourly dry deposition values are between 200 and $300 \mathrm{ng} \mathrm{m}^{-2} \mathrm{~h}^{-1}$ at 08:00 h UTC. Durnng the day the boundary layer helght increases, and the concentrations (not shown here) close to the surface decrease over the German Bight and at the North Frisian coast. They increase at the East Frisian coast. These model findings are consistent with the measurements (Fig. 2). Lower concentrations were measured at Westerhever and Helgoland during the

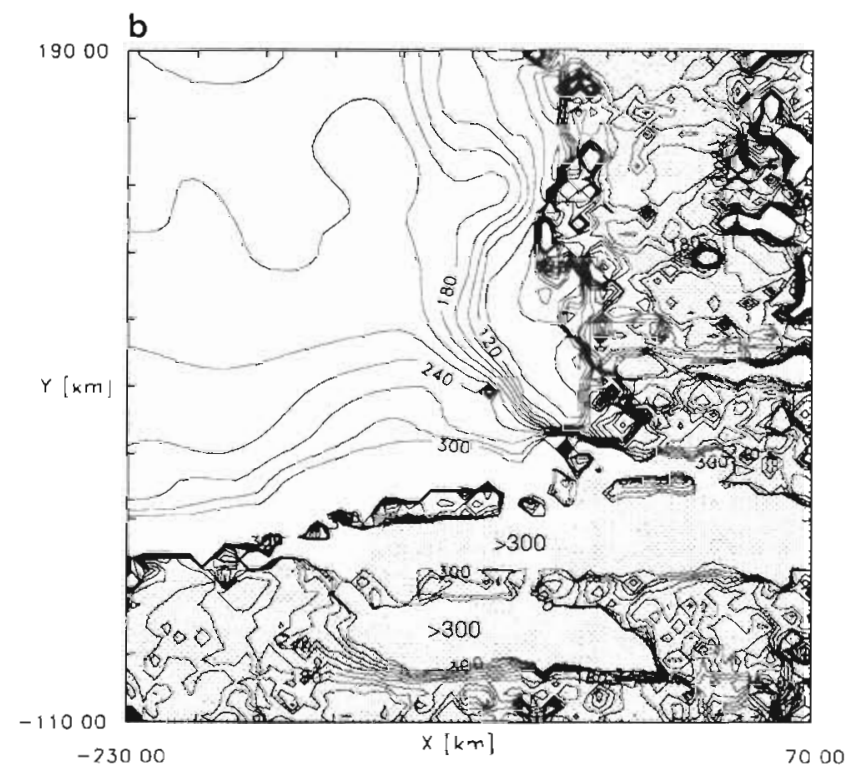

Fig. 7. Simulated hourly lead deposition for the area of the German Bight for Aprl 24. (a) 08.00 h UTC, (b) 1400 h UTC. Increment $1520 \mathrm{ng} \mathrm{m}^{-2} \mathrm{~h}^{-1}$ 
afternoon, whereas the concentrations were higher at Neuharlingersiel. The concentrations measured at these sites probably originate from sources close to the German Bight. However, large-scale transports were also important; they influenced the concentration level and caused the increase in concentration at FP 'Nordsee' and RV 'Valdivia' (see the section 'Measured concentrations' above).

The deposition velocity remains about the same further offshore during the day, but decreases in the convergence zone at the North Frisian coast $\left(1.2 \mathrm{~mm} \mathrm{~s}^{-1}\right)$. For this reason and due to the reduced concentrations, the atmospheric input is mostly lower in the afternoon compared to 08:00 h UTC, and minimum input values are to be found close to the North Frisian coast. Only at the East Frisian coastline, where higher deposition velocities and concentrations are modelled, is the atmospheric input higher at $14: 00 \mathrm{~h}$ than at 08:00 h UTC.

The simulated lead concentrations are around $13 \mathrm{ng}$ $\mathrm{m}^{-3}$ at RV 'Valdivia'. This value is lower by up to a factor of 3 than the concentrations measured there on April $24\left(32,17\right.$ and $13 \mathrm{ng} \mathrm{m}^{-3}$; Fig. 2a). There are 3 possible explanations. The simulated wind field gives a wind direction for the drift area which is $30^{\circ}$ too far to the north, and thus some sources in Schleswig-Holstein might not have contributed to the concentrations modelled for the measurement site RV 'Valdivia'. However, this effect seems to be of minor importance since the backward trajectories presented in Fig. 3 indicate that the contaminants have been transported over Denmark. The second reason might be the emis- sion data. While these were too high for Germany, the emission values estimated for the southern part of Denmark were too low and did not include industrial point sources. However, only the very southern part of Denmark is included in the model calculations and most of the sources there are included. The third reason again focuses on missing emission data. These might not be missing in the model area itself, but fluxes across the lateral boundaries - which can include influences of remote sources - might be underestimated. In the simulations they are assumed to produce background concentration values outside the model area. If long-range transport were included in the model calculations, these values would have to be considerably higher. It can be concluded from mesoscale model results and backward trajectories that during the first measurement interval on April 24 at least $50 \%$ of the concentrations measured at RV 'Valdivia' had sources outside the model area and that long-range transport was responsible for the increase in concentration. Sources at a distance of up to $100 \mathrm{~km}$ may have caused concentrations of $13 \mathrm{ng} \mathrm{m}^{-3}$ for the day examined.

\section{CALCULATED ATMOSPHERIC INPUT - MERGED MEASUREMENT AND MODEL RESULTS}

Fig. 8 shows lead deposition values calculated with 3 different methods at the 5 sampling sites for the period of the drift experiment. The dry deposition rates, $F_{\mathrm{d} 1}$, are based on the concentration measurements and an average deposition velocity for lead of $0.17 \mathrm{~cm} \mathrm{~s}^{-1}$,

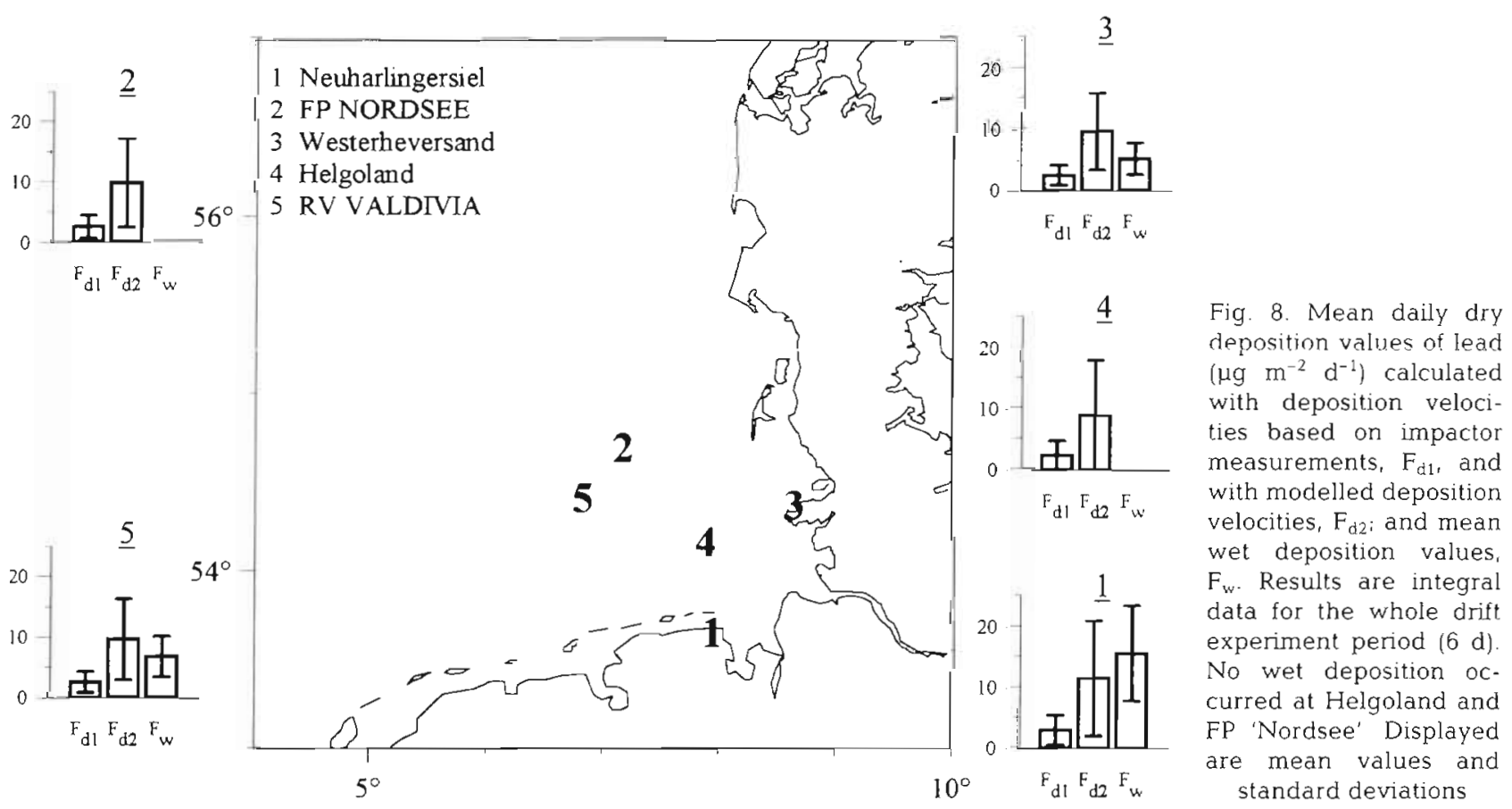


derived from impactor measurements. These mark the lower limit for dry deposition values (see the section 'Model results' abovel. The upper limit for dry deposition rates is given by $F_{\mathrm{d} 2}$, which is calculated from measured concentrations and modelled deposition velocities. The wet deposition rates, $F_{w}$ are calculated from sampled precipitation amounts and lead concentrations measured in the rain samples.

In general, dry deposition seems to be representatively measured, because deposition values are at about $3 \mu \mathrm{g} \mathrm{m}^{-2} \mathrm{~d}^{-1}$ for $F_{\mathrm{d} 1}$ and at about $10 \mu \mathrm{g} \mathrm{m}^{-2} \mathrm{~d}^{-1}$ for $\mathrm{F}_{\mathrm{d} 2}$ for all measurement sites. Wet deposition values differ. They lie between minimum and maximum dry deposition values at the measurement sites RV 'Valdivia' and Westerhever. Based on these measurements, about half of the atmospheric input into the German Bight was caused by dry and half by wet deposition during the drift experiment. However, the greater proportion of wet deposition at Neuharlingersiel (about $70 \%$ of the total) shows the uncertainty of this conclusion when it is applied to the whole German Bight. The enhanced wet deposition at Neuharlingersiel is caused by the more frequent rain events in that area. The low rain amounts at Helgoland (below $0.1 \mathrm{~mm}$ for the drift period) result in negligible wet deposition values here. The different results show that an integration period of $6 \mathrm{~d}$ is too short to calculate area-representative wet deposition values, due to the random occurrence of precipitation.

During the drift experiment, the atmospheric lead input into the German Bight was low in the area of Helgoland, whereas it was a factor of 10 higher at the East Frisian coastline. Deriving yearly input data based on these results for the whole German Bight, the values are between $25 \mathrm{t} \mathrm{yr}^{-1}$ (based on Helgoland data, $F_{d 1}$ ) and 250 t yr $^{-1}$ (based on Neuharlingersiel data, $F_{d 2}$ plus $F_{w}$ ). Yearly means calculated from long term measurements show a lower range (110 to $240 \mathrm{t} \mathrm{yr}^{-1}$; recalculated values based on Schlünzen 1994a). The enlarged range resulting from the present $1 \mathrm{wk}$ exper- iment underlines the importance of long-term measurements when mean atmospheric input values are to be estimated. At the same time, it shows the importance of high resolution measurements when causes of high or low concentrations in seawater are to be investigated.

Assuming that the atmospheric input of lead compounds ( 3 to $30 \mu \mathrm{g} \mathrm{m}^{-2} \mathrm{~d}^{-1}$ ) was completely absorbed by the sea water, the average daily increase of lead in the upper meter of the water column was between 3 and $30 \mathrm{ng} \mathrm{kg} \mathrm{kg}^{-1}$. This value is 1 to $100 \%$ of the observed low lead concentrations in the water and is far beyond or in the range of observed changes in concentrations. For the measurement site RV 'Valdivia', where the measurements in the water column were performed, the mean total deposition was about $9 \mathrm{ng}$ $\mathrm{kg}^{-1} \mathrm{~d}^{-1}$. However, for individual days the total deposition was considerably higher.

Fig. 9a shows the lead concentration in air and the dry deposition values calculated with the modelled deposition velocity of lead. Individual lead dry deposition values range from 1 to $25 \mu \mathrm{g} \mathrm{m}^{-2} \mathrm{~d}^{-1}$ and are thus up to a factor of about 3 higher than the mean value of $9 \mu \mathrm{g} \mathrm{m}^{-2} \mathrm{~d}^{-1}$. Furthermore, the maximum dry deposition is only about $10 \%$ of the total deposition (Fig. 9b). The difference was caused by 1 rain event which lasted for $5 \mathrm{~h}$ only, but considerably influenced the total deposition. With a total deposition of $220 \mu \mathrm{g} \mathrm{m}^{-2}$ $\mathrm{d}^{-1}$ the daily increase of lead concentration in the upper meter of the water column was about $200 \mathrm{ng}$ $\mathrm{kg}^{-1} \mathrm{~d}^{-1}$ ), a value well in the range of measured sea water concentrations and their changes.

\section{CONCLUSIONS}

The results presented on atmospheric input into the German Bight elucidate possible causes of high concentrations and show the range of input data. The integral dry deposition values were within the same order
Fig. 9. (a) Atmospheric lead concentrations, $\mathrm{C}_{\mathrm{p} b}$ (ng $\mathrm{m}^{-3}$ ), and lead dry deposition rates, $\mathrm{F}_{d}(\mathrm{~Pb})$ ( $\left.\mu \mathrm{g} \mathrm{m}^{-2} \mathrm{~d}^{-1}\right)$, calculated with the modelled deposition velocity for lead. (b) Dry deposition rates, $F_{d}(\mathrm{~Pb})$, compared with total deposition rates, $F_{1}(\mathrm{~Pb})$; note difference in scales
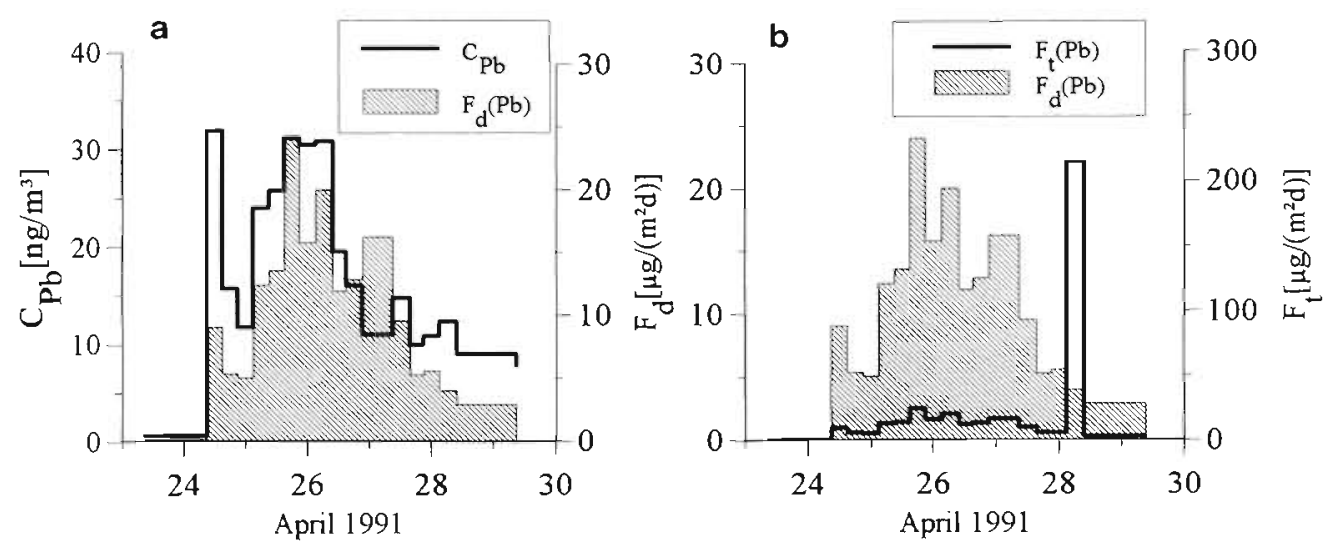
of magnitude at all sites in the measurement area. In the case of precipitation, wet deposition could become the main contributor to the total deposition, and the values differed considerably between the measurement sites (up to a factor 10). A sampling time of $1 \mathrm{wk}$ did not result in similar deposition values over an area of about 120 by $120 \mathrm{~km}^{2}$. This should be considered when comparing results from large-scale models with single measurements. It can be assumed that for longer time periods the probability that similar rain amounts will be measured at all sites increases and measurements and model results will become more comparable. Due to the relevance of wet deposition for the total deposition, wet and dry deposition values should be determined separately, in measurements as well as in models. These data allow comparisons even for short time intervals, as shown in the present paper (section 'Model results').

The differences in the deposition velocities calculated from impactor measurements and in the model have been explained by the used aerosol size distributions ('Model results'). The 2 values for dry deposition data presented in this paper mark the lower and upper limits. For future model studies and evaluations of measurement data, the bimodal structure of the aerosol size spectrum and the growing of hygroscopic particles over water due to humidity should be taken into account.

Models have been shown to be a helpful tool for the interpretation of measurements and they can help to pinpoint main source areas. In the work described here, 2 models were applied for different scales (backward trajectories, mesoscale model). The model results underline the importance of long-range transport, which can be responsible for up to $50 \%$ of the measured concentrations. Mesoscale phenomena were also found to influence the concentrations. The present measurement and model case study verifies again that sources in the area of the German Bight as well as remote sources contribute substantially to the atmospheric lead input.

The range of high-resolution total deposition data and the resultant concentration changes in the water column (section 'Calculated atmospheric input...') underline the importance of high-resolution data when investigating changes in the water column. The $6 \mathrm{~d}$ mean value for the drift experiment $\left(9 \mathrm{ng} \mathrm{kg} \mathrm{kg}^{-1} \mathrm{~d}^{-1}\right)$ was not sufficient to reflect possible minima and maxima in atmospheric input. These lay an order of magnitude below or a factor of 25 above the mean values. Since they are crucial parameters when explaining transfer processes in the water column, they should be measured and modelled with a high temporal and spatial resolution, at least in investigations which aim to clarify transfer processes in the ocean.
Acknowledgements. We thank Ursula Bredthauer, Holger Gerwig, and Götz Steinhoff at the Institut für Anorganische und Angewandte Chemie. Universität Hamburg, for the chemical analysis, Martina Falke (now at the Umweltbehörde Hamburg) for taking the meteorological measurements on board RV 'Gauss', and Volker Reinhardt at the Meteorologisches Institut, Universität Hamburg, for calculating the backward trajectories. We thank the German Weather Service for kindly making the meteorological data available to us. This work was funded by the Universitat Hamburg and by the Minister für Forschung und Technologie, Bonn, under grant number 03F0558A1 The authors are responsible for the contents of this publication.

\section{LITERATURE CITED}

Brockmann UH, Raabe $T$, Nagel K, Haarich M (1997) Measurement strategy of PRISMA; design and realisation. Mar Ecol Prog Ser 156:245-254

Brutsaert W (1975) The roughness length for water vapour, sensible heat, and other scalars. J Atmos Sci 32:2028-2031

Chang JS, Brost RA, Isaksen ISA, Madronich S, Middelton P, Stockwell WR, Walcek CJ (1987) A three dimensional Eulerian and deposition model: physical concepts and formulation. J Geophys Res 92:14681-14700

Dannecker W. Hinzpeter H, Kirzel HJ, Luthardt H, Kriews M, Naumann K, Schulz $M$, Schwikowsky $M$, Steiger $M$, Terzenbach U (1994) Atmospheric transport of contaminants, their ambient concentration and input into the North Sea. In: Sündermann J (ed) Circulation and contaminant fluxes in the North Sea. Springer-Verlag, Berlin, p $138-189$

Dunst $M(1982)$ On the vertical structure of the eddy diffusion coefficient in the PBL. Atmos Environ 16:2071-2074

Garratt JR, Hicks BB (1973) Momentum, heat and water vapour transfer to and from natural and artificial surfaces. Q J R Meteorol Soc 99:680-687

INC (1987) Der Qualitätszustand der Nordsee-Zusammenfassung. Report by Wissenschaftlich-Technische Arbeitsgruppe zur zweiten Internationalen Nordseekonterenz. Her Majesty's Stationery Office, London

Karbe L, Aletsee L, Dürselen CD. Heyer K, Kammann U, Krause M, Rick HJ, Steinhardt H (1994) Bioaccumulation and effects of plankton and benthos on the fate of contaminants. In: Sündermann J (ed) Circulation and contaminant fluxes in the North Sea. Springer-Verlag, Berlin, p 555-597

Kersten M, Förstner U, Kriews $M$. Krause P, Dannecker W, Garbe CD, Hock M. Terzenbach U, Grassl H (1992) Pollution source reconnaissance using stable lead isotope ratios $\left({ }^{266 / 207} \mathrm{~Pb}\right)$. In: Vernel JP (ed) Trace metals in the environment: impact of heavy metals on the environment. Elsevier, Amsterdam, p 311-325

Kersten M, Kriews M, Kühn W, Rick HJ (1994) Combined effects of abiotic and biotic factors on heavy metal fluxes. In: Sündermann J (ed) Circulation and contaminant fluxes in the North Sea. Springer-Verlag, Berlin, p 598-619

König P, Schrum C (1997) Hydrographic observations and model results from a PRISMA drift experiment. Mar Ecol Prog Ser 156:255-261

Krause P, Kriews M, Dannecker W, Garbe-Schönberg CD, Kersten M (1994) Determination of ${ }^{206 / 207} \mathrm{~Pb}$ isotope ratios by ICP-MS in particulate matter from the North Sea environment. Fresenius J Analyt Chem 347:324-329

Kriews M (1992) Charakterisierung mariner Aerosole in der Deutschen Bucht sowie ProzeBstudien zum Verhalten 
von Spurenmetallen beim Übergang Atmosphäre/Meerwasser. Schriftenreihe Angewandte Analytik, Institut für Anorganische und Angewandte Chemie, University of Hamburg 15

Moll A (1997) Phosphate and plankton dynamics during a drift experiment in the German Bight: simulation of phosphorus-related plankton production. Mar Ecol Prog Ser 156:289-297

Münch G. Axenfeld F (1990) Emissions-Datenbasis für die Untersuchung und Bewertung des Pb-Eintrags über die Atmosphäre in Nord- und Ostsee mit Hilfe eines mesoskaligen Ausbreitungsmodells (GESIMA). In: Eppel DP, Kapitza H (eds) Simulation des Transports und der Deposition atmosphärischen Bleis in der norddeutschen Küstenregion. Abschlußbericht, Forschungsprojekt UFAFB 92-10402 583. GKSS-Forschungszentrum, Geesthacht

Niemeier U, Schlünzen KH (1993) Modelling steep terrain influences on flow patterns at the isle of Helgoland. Beitr Phys Atmosph 66:45-62

QSR (1993) Quality status report of the North Sea 1993. Report on sub-region 7a. Salchow R (ed) Bundesamt für Seeschiffahrt und Hydrographie, Hamburg

Raabe TU, Brockmann UH, Dürselen CD, Krause M, Rick HJ (1997) Nutrient and plankton dynamics during a spring drift experiment in the German Bight. Mar Ecol Prog Ser $156: 275-288$

Schlünzen KH (1988) Das mesoskalige Modell 'METRAS'Grundlagen, Validierung, Anwendung. Hamburger Geophys Einzelschr A88

Schlünzen KH (1990) Numerical studies on the inland penetration of sea breeze fronts at a coastline with tidally flooded mudflats. Beitr Phys Atmosph 63:243-256

Schlünzen KH (1994a) Atmosphärischer Eintrag von Nährund Schadstoffen. In: Lozán JL, Lenz W, Rachor E, Reise $\mathrm{K}$, von Westenhagen $\mathrm{H}$ (eds) Warnsignale aus dem Wattenmeer-wissenschaftliche Fakten. Blackwell Wissenschafts-Verlag, Berlin, p 45-48

Schlünzen KH (1994b) Mesoscale modelling-overview on the German nonhydrostatic models. Beitr Phys Atmosph $67: 243-253$

Schlünzen KH, Bigalke K, Niemeier U, Lenz CJ, Lüpkes C, von Salzen K (1996) Concept and realisation of the mesoscale transport and fluid-model 'METRAS' METRAS Tech Rep 5, Meteorologisches Institut, University of Hamburg

Schlünzen KH. Krell U (1994) Mean and local transport in air. In: Sündermann J (ed) Circulation and contaminant fluxes in the North Sea. Springer Verlag, Berlin, p 317-344

Schlünzen KH, Pahl S (1992) Modification of dry deposition in a developing sea-breeze circulation-a numerical case study. Atmos Environ 26A: 51-61

This article was submitted to the editor
Schrum C, König P, Michaelsen K, Niemeier U, Pohlmann T (1997) Meteorological and oceanographic situation in the German Bight from 23 to 29 April 1991. Mar Ecol Prog Ser $156: 263-273$

Schulz M (1993) Räumliche und zeitliche Verteilung atmosphärischer Einträge von Spurenelementen in die Nordsee. Schriftenreihe Angewandte Analytik, Institut für Anorganische und Angewandte Chemie, University of Hamburg 17

Schulz M, Stahlschmidt T, Maenhaut W, Francois F, Larsen SE (1994) The change of aerosol size distributions measured in a Lagrangian-type-experiment to study deposition and transport processes in the marine atmosphere. In: Proceedings of the EUROTRAC Symposium, April 1994, Garmisch-Partenkirchen, Germany. EUROTRAC Office, Garmisch-Partenkirchen, p 702-706

Seinfeld JH (1986) Atmospheric chemistry and physics of air pollution. Wiley \& Sons, New York

Spokes L, Jickells T, Rendell A, Schulz M, Rebers A, Dannecker W, Krüger O, Leermakers M, Baeyens W (1993) High atmospheric nitrogen deposition events over the North Sea. Mar Pollut Bull 26:698-703

Steiger M Schulz M, Schwikowski M, Naumann K, Dannecker W (1989) Variability of aerosol size distributions above the North Sea and its implication to dry deposition estimates. J Aerosol Sci 20:1229-1232

Sündermann J (1997) The PRISMA project: an investigation of processes controlling contaminant fluxes in the German Bight. Mar Ecol Prog Ser 156:239-243

Voldner EC, Barrie LA, Sirois A (1986) A literature review of dry deposition of oxides of sulphur and nitrogen with emphasis on long-range transport modelling in North America. Atmos Environ 20:2101-2123

Walcek CJ, Brost RA, Chang JS (1986) $\mathrm{SO}_{2}$, sulfate and $\mathrm{HNO}_{3}$ deposition velocities computed using regional landuse and meteorological data. Atmos Environ 20:949-964

Warmenhoven JP, Duiser JA, de Leu LTh, Veldt C (1989) The contribution of the input from the atmosphere to the contamination of the North Sea and the Dutch Wadden Sea. Rep No. R89/349A, TNO, Apeldorn

Weseley ML. Hicks BB (1977) Some factors that affect the deposition rate of sulfur dioxide and similar gases on vegetation. J Air Pollut Control Assoc 27:1110-1116

Wu Z, Schlünzen KH (1992) Numerical studies on the local wind structures forced by the complex terrain of Qingdao area. Acta Meteorol Sin 6:355-366

Zebel G (1979) Modellrechnungen über den Einfluß des Windes auf die Einsaugkoeffizienten von Staubteilchen für zwei verschiedene Probenahmeköpfe. Staub Reinhaltung Luft 39:349-362

Manuscript received: January 2, 1997

Revised version accepted: June 2, 1997 